\title{
Determining the Priorities of the Development of EU Research Universities Based on the Analysis of Rating Indicators of World-Class Universities
}

\author{
Maksym W. Sitnicki \\ Taras Shevchenko National University of Kyiv \\ Volodymyrska 60, \\ Kyiv 01033, Ukraine \\ E-mail: maksym.sitnicki@ukr.net
}

Abstract: The object of this research is the activity of 25 leading research universities in the world. One of the most problematic issues is the in-depth analysis of the ranking indicators of world-class research universities in order to identify the priorities for the development of research universities in the European Union. The following scientific methods were used in the research: generalizations, analysis, synthesis, graphical method, and also comparison method. The study is based on data on the global university rankings in QS World University Rankings 2018 and empirical data from publicly available sources provided by the research universities.

The article also systematizes the scientific views of the leading scientists of Europe and the world on the course of development of research universities and analyses the experience of implementing joint scientific projects in the EU countries. The importance of international cooperation between research universities in the fields of academic mobility and scientific research is underlined due to the fact that the global challenges and prospects that the research universities in the European Union and the world are facing are transient and create a tough competitive environment. Strengthening their leadership potential and developing entrepreneurial thinking has been revealed as a modern trend in the development of research universities.

The article characterizes the 25 best world-class research universities, and the factors which have enabled them to uncover their strengths 
and systematize the key areas of in-depth specialization. The contrasting differences between the analysed research universities are shown, as there are significant disparities in the total number of students, foreign students and staff of research universities, showing fundamentally different approaches to the organization of educational and research processes, even within a single country. This is due to the fact that the ratio of student per staff representative significantly affects the quality of education.

The author proposes the key development priorities for research universities in the European Union, which consist in intensified work on: academic reputation; the number of foreign students; reputation of employers; improvement of the ratio of the number of students to the number of staff; improvement of quality and increase in the number of citations of scientific publications by university researchers; increasing the share of the university's participation in international educational and scientific networks of other countries and continents.

Keywords: characteristics of research universities, global rating of research universities, rating indicators, strategic directions of development of EU research universities

\section{Introduction}

The educational and research leaders of the world to date are authoritative universities in the United States, Great Britain, Switzerland, Singapore, Australia and China. It is the research universities of these countries that are listed on the first page of the top 25 authoritative global QS rating ( $Q S$ World University Rankings, 2018).

Under the conditions of the total development of digital technologies and significant changes in channels and modes of knowledge transfer (OECD, 2017), if the rating positions of research universities cannot build their development strategy in accordance with current trends, they will gradually decline. An important feature is that on the first page of this rating, only universities in the UK are represented among European research universities. If plans for the UK's exit from the EU are implemented, in fact, there may emerge a situation that among the best research universities in the world there will not be a single European one. To prevent such a scenario from happening, there is an urgent 
need for a detailed analysis of the main ranking indicators of world-class research universities and the search for opportunities for the strategic development of European universities in these key areas. The topic of this study is relevant given these facts.

\section{The aim and objectives of research}

The aim of this research is to determine the priorities for the development of research universities in the European Union on the basis of an analysis of the ranking indicators of world-class universities. The study poses the following tasks:

- Identifying the main characteristics of 25 world-class research universities;

- Comparing the number of students, foreign students and staff of research universities, providing the educational and scientific process;

- Systematizing and comparing the main rating indicators of the global university ranking QS;

- $\quad$ Proposing strategic directions for the development of research universities in the European Union with a view of improving their positions in the global ranking.

\section{Literature review and discussion}

The scientific problem of the development of research universities and aspects of assessing the results of their activities has been tackled by a significant number of authoritative scientists. Daugèlienè (2013) has written an in-depth analysis of the scientific works of well-known economists and philosophers (since 1873), based on theoretical arguments about the need for changes in the world economy. The author notes that according to the European Commission, about a fifth of the growth in the economies of the EU countries over the past 50 years depended on the integration of the world economy, that is, globalization (Daugèliené, 2013). Supyan (2009) has carried out a comprehensive analysis of the factors that can influence the challenges of society and the economy in the 21 st century, systematizing the criteria for the manifestation of globalization. In the study, issues of the global impact of research universities on the economies of the countries in which they functioned were discussed in detail (Supyan, 2009). Also, effective mechanisms for the deep integration of science and education are 
proposed. Next to this, a lot of attention has been devoted to the study of world experience in the work. The methodological foundations of the international competitiveness of research universities have been systematized in a paper by Pavlenko, Antoniuk and Vasylkova (2014). In their work, considerable attention has been paid to studying the experience of establishing world-class universities and to analysing the competitive situation of Ukrainian higher education institutions. Strategic directions of the development of research universities in Ukraine have been determined. Other authors (e.g., Keikha, Hoveida \& Yaghoubi, 2017) believe that competent leadership is an important part of the education system of each country and could potentially play a key role in achieving its global goals. New models try to approach leadership through the prism of a creativity and intellectuality. This work is aimed at developing the intellectual model of leadership for research universities.

Kerikmäe and Chochia (2016) have discussed in detail the current issues of the EU Eastern Partnership, taking into account the geopolitical challenges of integration into the EU. The scientists express the idea that the Eastern Partnership strategies should be revised so that they would be more mutually beneficial, and not based solely on the EU agenda. The value of their study is that it is a powerful interdisciplinary scientific achievement, which is accomplished in cooperation between scientists from the Eastern Partnership countries and EU countries. Thus, the prospects for cooperation in various fields, research and educational particulars are comprehensively identified (Kerikmäe \& Chochia, 2016). The effectiveness of the interaction of universities and industry in the implementation of research projects in the Baltic region is discussed in the paper by Murashova and Loginova (2017). The main goal of their study is an analysis of the level of scientific interest of researchers from the Baltic Sea region in interaction with each other for the growth of publication activity and the quality of scientific research (Murashova \& Loginova, 2017). An important issue of ensuring free movement of persons in the European Union has been tackled in the publication by Junevičius and Daugeliene (2016). This issue is important in terms of the impact of the free movement of EU citizens on the level of cooperation of scientists in EU research universities. The authors focus on the threatening trends in the EU that could lead to a significant restriction of the rights of citizens in terms of free movement and residence in the territory of the EU Member States (Junevičius \& Daugèlienè, 2016). Another research is devoted to the development of the IT products market and the challenges that it creates for the European Union and its Member States (Säär \& Rull, 2015). The authors note that each EU country has its own policy regarding the transfer of technology and ownership of digital services, but the lack of readiness of 
infrastructure, legislation and stakeholders for cross-border exchanges creates a threat to the full exchange of IT technologies. The products of this sphere are of strategic importance for exchange of scientific information and intellectual products of inventors in research universities of the EU and the world. (Säär \& Rull, 2015)

The paper by Gunther et al. (2017) assesses the economic advantages and disadvantages of eastern expansion of the European Union for the old and new EU Member States. Particular attention is paid to the strategies of crossborder scientific cooperation between Germany and Poland. The authors have conducted an empirical study on the example of the European University Viadrina (EUV), which was recently founded in the German-Polish border region, and demonstrates the positive results of German-Polish cooperation on the basis of productive joint publishing activity (Gunther et al., 2017). In a study by Schuch (2014), the participation of EU-13 countries in the European Research Framework Programs is unveiled. The European Union's activities aimed at strengthening and expanding participation in the framework of the European Framework Program for Research and Development HORIZON 2020 are systematized. Conclusions are given on why, despite the great efforts, cooperation within the EU-13 remains low (Schuch, 2014). The work by Chataway, Parks and Smith (2017) focuses on increasing the level of openness of university science, but the issue of the effectiveness of publishing activity prompts considerable discussion.

In their study, Perez Vico, Schwaag Serger, Wise and Benner (2017), analyse the interaction of the knowledge triangle on the example of three different Swedish universities, that is, the links between research, education and innovations created in the universities. It shows how they manifest themselves in research universities and their development strategies. Also Cervantes (2017), in the framework of the discussion on the introduction of best practices aimed at increasing the effectiveness of research universities, focuses on the need to improve the impact on the society and the economy of the triangle of knowledge. Unger and Polt (2017) highlight the key features of this concept as the basis for innovation in universities. The work by Eghbal et al. (2017) is devoted to the impact of the talent management process on the results of their research. This study is aimed at determining the impact of effective management components on the results of research by teachers.

The issue of the effectiveness of global ranking systems has been professionally studied by scientists of the Institute of Higher Education of the National Academy of Pedagogical Sciences of Ukraine. The scientific work by Kurbatov (2008) 
updates the use of university catalogs to assess their activities and determine the state of the education sector as a whole. In his work the author considers the influence of university ratings on global academic policy (Kurbatov, 2015). Scientists of the Taras Shevchenko National University of Kyiv (Zhylinska \& Sitnitskiy, 2018) study in detail the methodological foundations of the existing catalogs of research universities in the world. The authors propose their own approach to the determination of rating indicators and their content, which allows to objectify the results of the ranking of research universities in the future assessment. The differences in the top 25 business schools of research universities in the world are systematized by Sitnitskiy (2018). Business schools help ensure that MBA students receive a key competence-the entrepreneurial way of thinking. Compared with similar known traditional models of development of research universities, this guarantees the renewal of the scientific potential of research universities and provides opportunities for increasing competitiveness at the global level.

The analysis of literary sources makes it possible to systematize the current directions of scientific research in terms of development of education and science in Europe and the world. It is established that the issues concerning priorities for research are the search for effective mechanisms for the deep integration of science and education in the countries of the European Union and the Eastern Partnership. For this, cooperation strategies and more pragmatic relations should be revised. Changes are to be made in the priorities of research universities of the European Union in order to increase the effectiveness of their participation in the European research framework programs. The importance of the free movement of EU citizens and the liberalization of visa requirements for third countries was emphasized with the aim of developing cross-border scientific cooperation and the formation of international research networks between research universities in Europe and partners. This cooperation is of strategic importance for the exchange of scientific information, creating new knowledge and increasing the effectiveness of publicity activities. A modern trend in the development of research universities in the direction of building an intellectual model of leadership in global ranking systems of world-class universities is revealed. Effective management of scientific research results of research university scientists allows occupying high positions in university rankings of the global academic market. This position strengthens the academic reputation of research universities and presents their educational and scientific potential to other potential partners. Taking this into account, the research of rating systems is a topical and timely direction. 


\section{Methodology and results}

To achieve the aim and solve the tasks of the work during the research, the following scientific methods were used: generalization, analysis, synthesis, graphical method, and comparison method. The study was conducted on the basis of data from the global university QS rating and data collected empirically from publicly available sources of the research universities.

The ranking positions of the 25 worlds' best research universities are presented in Table 1, showing their list, country of origin and rating position based on the global rankings (QS World University Rankings, 2018).

Table 1. The global rating of top 25 research universities, 2018

\begin{tabular}{|l|l|l|l|}
\hline No. & Research university & Country & Rank \\
\hline 1 & Massachusetts Institute of Technology (MIT) & USA & 1 \\
\hline 2 & Stanford University & USA & 2 \\
\hline 3 & Harvard University & USA & 3 \\
\hline 4 & California Institute of Technology (Caltech) & USA & 4 \\
\hline 5 & University of Cambridge & UK & 5 \\
\hline 6 & University of Oxford & UK & 6 \\
\hline 7 & UCL (University College London) & UK & 7 \\
\hline 8 & Imperial College London & UK & 8 \\
\hline 9 & University of Chicago & UK & 9 \\
\hline 10 & ETH Zurich - Swiss Federal Institute of Technology & Switzerland & 10 \\
\hline 11 & Nanyang Technological University, Singapore (NTU) & Singapore & 11 \\
\hline 12 & École Polytechnique Fédérale de Lausanne (EPFL) & Switzerland & 12 \\
\hline 13 & Princeton University & USA & 13 \\
\hline 14 & Cornell University & USA & 14 \\
\hline 15 & National University of Singapore (NUS) & Singapore & 15 \\
\hline 16 & Yale University & USA & 16 \\
\hline 17 & Johns Hopkins University & USA & 17 \\
\hline 18 & Columbia University & USA & 18 \\
\hline 19 & University of Pennsylvania & USA & 19 \\
\hline 20 & The Australian National University & Australia & 20 \\
\hline 21 & Duke University & USA & $=21$ \\
\hline 22 & University of Michigan & USA & $=21$ \\
\hline 23 & The University of Edinburgh & UK & $=23$ \\
\hline 24 & King's College London & UK & $=23$ \\
\hline 25 & Tsinghua University & China & 25 \\
\hline & & & \\
\hline
\end{tabular}

Source: Compiled by the author on the basis of QS World University Rankings, 2018 
Figure 1 presents the general results of the evaluation of the world-class research universities listed in Table 1.

Figure 1. The general rating of research universities in the world, $\%$

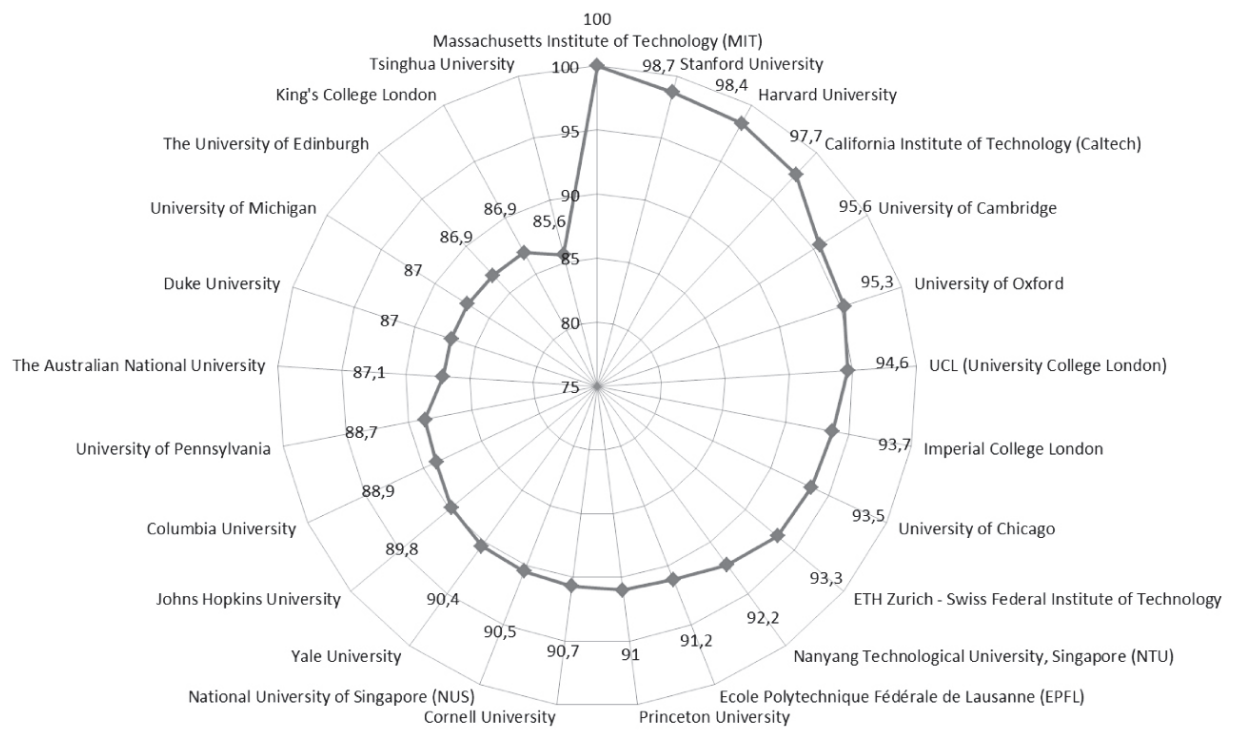

$\multimap$ overall score, \%

Source: Compiled by the author on the basis of QS World University Rankings, 2018

Figure 1 shows that the world leader is Massachusetts Institute of Technology (USA), which received an expert assessment of $100 \%$. The difference between this university and the second-ranking university is $1.3 \%$. Tsinghua University (China) ends the list of the top 25 research universities in the world with an expert assessment level of $85.6 \%$. It is the only Chinese university in the top 25 ranking. Each of these research universities will be characterized at further length below.

Massachusetts Institute of Technology (MIT) is a privately-owned research university, founded in 1861 in Cambridge, Massachusetts, USA. Today it is the best university in the world and has held this position for several years in a row. The strengths of the university are: opportunities for employment of graduates; educational process; material basis for training and research; high level of internationalization; innovation; qualification of scientific and pedagogical staff and inclusiveness. In the laboratories of the university, research is conducted on topical issues of peace. (MIT, 2018) 
Stanford University is a privately-owned research university. It occupies the 2nd place among the best universities in the world and is located in Silicon Valley in California, USA. The strengths of the university are: arts and humanities; technology and technology; life sciences and medicine; social sciences and business management; natural sciences. (Stanford University, 2018)

Harvard University is a privately-owned research university, the oldest university in America, the 3rd best university in the world, and also part of the Ivy League. The strengths of the university are: life sciences and medicine; social sciences and management. Harvard Business School ranks first in the world. (Harvard University, 2018)

California Institute of Technology (Caltech) is a privately-owned research university, located in Pasadena in California, USA and the 4th best university in the world. The strengths of the university are: research, innovation, educational and research infrastructure; qualification of scientific and pedagogical staff; it is especially strong in the study of technology, engineering, mathematics, chemistry, biology, and the natural sciences. Caltech is a small but powerful research institution. (California Institute of Technology, 2018)

University of Cambridge is a state-owned research university. Founded in 1209, Cambridge University ranks 5th in the world, has a very rich history with the oldest Peterhouse College, which dates back to 1284. The strengths of the university are: research; innovation; teaching English and literature, geography, history, modern languages and equipment; natural sciences and many others (University of Cambridge, 2018).

University of Oxford is a state-owned research university. The British Oxford University is the 6th best university in the world. The strengths of the university are: research; conditions for training; innovation; opportunities for employment; English language and literature; geography; archeology; anatomy and physiology; art and humanities. (University of Oxford, 2018)

University College London (UCL) is a state-owned research university. It is one of the best multidisciplinary universities in the world, ranks 7 th in the global ranking and has an international reputation for the quality of research and teaching. The university's strengths are: leadership in research; teaching of advanced experience in subjects: medicine, foreign languages, jurisprudence, engineering, history and astrophysics; interdisciplinary training is encouraged. (University College London, 2018) 
Imperial College London is a state-owned research university. London Imperial College, a unique institution in the UK, occupies the 8th position in the world and focuses exclusively on science, technology, medicine and business. Imperial College is located in South Kensington, London, in an area called Albertopolis. The strengths of the university are: access of students to world-class researchers; practical solution of global problems by scientific means; more than half of the students are of international background. (Imperial College London, 2018)

University of Chicago is a privately-owned research university. The University of Chicago, founded in 1890 in the United States, is a research and development university, ranking 9th in the world. The strengths of the university are: scientific achievements; its more than 140 research centers and research institutes working outside the university; and the largest university publishing house in the United States. (University of Chicago, 2018)

ETH Zurich - Swiss Federal Institute of Technology is a state-owned research university. The university occupies the 10th position in the global ranking and is located in Zurich, Switzerland. The university appreciates academic freedom, responsibility, entrepreneurial spirit and openness to the world. Since 1855, this university of science and technology has been the center of knowledge and innovation. The strengths of the university are: its 500 professors; international students from more than 120 countries; research institute of scientific work; solving the global problems that humankind is faced with. (ETH Zurich, 2018)

Nanyang Technological University, Singapore (NTU) is a state-owned research university. The university is an autonomous educational and research institution, it occupies the 11th place in the world and is located in Singapore. It is the most successful university in the world and reaches fifty years of age. The strengths of the university are: technology; electricity and electronic equipment; materials science; informatics and communication; chemical technologies; natural sciences; training; information systems; social sciences and management of economy and management of leisure; linguistics. (NTU, 2018)

École Polytechnique Fédérale de Lausanne (EPFL) is a state-owned research university. Founded in 1853, the university occupies the 12th place in the world and is located in Lausanne, Switzerland. The strengths of the university are: Humanities College; results of research in physical sciences and engineering. There are training programs for all levels organized in seven schools: basic sciences; machine building; architecture, civil and environmental engineering; computer and communication sciences; life sciences, technology management. (EPFL, 2018) 
Princeton University is a privately-owned research university. Founded in 1746, Princeton University is one of the oldest universities in the United States and ranks 13th in the world. The strengths of the university are: a strong material base; impressive academic reputation; powerful scientific schools. (Princeton University, 2018)

Cornell University is a privately-owned research university. It was founded in 1865 , is part of the Ivy League and is located in Ithaca, New York, USA. Cornell University holds the 14th place in the world ranking. The strengths of the university are: modern scientific laboratories; veterinary medicine; agriculture and forestry; hospitality and leisure management; biological sciences; English and literature. (Cornell University, 2018)

National University of Singapore (NUS) is a state-owned research university. It is the leading global university in Singapore, based in Asia. Ranking 15th in the world, the university offers a global approach to education and research, focusing on Asian perspectives and experiences. The strengths of the university are: 17 faculties and schools in three campuses; transformational education, a broad curriculum that is filled with interdisciplinary courses; international students from 100 countries; favorable and innovative environment for promoting creative entrepreneurship; an integrated and multidisciplinary approach to research; 30 research institutes and centers. (NUS, 2018)

Yale University is a privately-owned research university. Founded in 1701, it is part of the Ivy League and is based in New Haven, Connecticut, USA. Yale University is the 16th best university in the world. The strengths of the university are: research; innovation; internationalization; legal research, English and literature; history; policy; arts and humanities. (Yale University, 2018)

Johns Hopkins University is a privately-owned research university. Johns Hopkins University is the 17th best university in the world and its strengths are: training nurses; biological and medical sciences; anatomy and physiology; employment. Compared to other American universities in the past 36 years, John Hopkins University has invested heavily in research. (Johns Hopkins University, 2018)

Columbia University is a privately-owned research university. The university ranks 18th among the best in the world and is included in the Ivy League. The university was founded in 1754 and is located in New York City. Columbia University is one of the world's most important academic institutions. The strengths of the university are: its Faculty of Arts and Sciences; research on global challenges in climate, health and technology; the Earth Institute; medical 
center; ensuring global leadership in research, health, medical education and patient care; more than 200 research centers and institutes covering a wide range of interdisciplinary work. (Columbia University, 2018)

University of Pennsylvania is a privately-owned research university. It was founded in 1740, is part of the Ivy League and has a long and outstanding academic reputation. It ranks 19th in the world and is located in Philadelphia, Pennsylvania, USA. The strengths of the university are: inclusiveness; various online activities for the public; culture of innovation, entrepreneurship and interdisciplinary cooperation; active cooperation with national and global research communities. (University of Pennsylvania, 2018)

The Australian National University ( $A N U$ ) is a state-owned research university. It is the leading center of education and research, ranking 20th in the world and the first in Australia. The strengths of the university are: impressive indicators on the employment of graduates; flexible working conditions of scientific and pedagogical staff; opportunities for professional development; competitive compensation of labor; generous payment of pension; an innovative and creative atmosphere (ANU, 2018).

Duke University is a privately-owned research university, which was founded in 1838 and ranks 21st in the world. The university campus is located in North Carolina, USA. The university's strengths are: employment of students; theology; religious studies and theology; English language and literature; history, biological sciences; medicine; economics and econometrics; life sciences and medicine; the level of scientific research; innovation; own clinic. (Duke University, 2018)

University of Michigan is a state-owned research university, founded in 1817 and located in Ann Arbor, Michigan, USA. It is the oldest state university, and is now considered one of the best research institutions in the country. Michigan ranks 22 nd in the world. The strengths of the university are: global orientation; more than 200 study programs abroad on six continents and more than 65 foreign languages; has one of the highest number of graduates (more than 540,000). (University of Michigan, 2018)

The University of Edinburgh is a state-owned research university. It was founded in 1583 and is one of the leading universities in the world, occupying the $23 \mathrm{rd}$ position. The strengths of the university are: entrepreneurial and interdisciplinary culture; attraction to the educational and scientific process of the Nobel Prize laureates, pioneers and inventors; it is the largest provider of online distance learning in research universities of the Russell Group UK, 
offering more than 60 online programs; teaching and research skills; more than 500 undergraduate courses; 300 training courses of masters and 135 scientific directions; employment opportunities. (The University of Edinburgh, 2018)

King's College London is a state-owned research university and one of the twenty-three best universities in the world. King's College has an outstanding reputation of world-class training and modern research. The strengths of the university are: humanities and legal sciences; a wide range of healthcare sectors, including psychiatry, medicine, nursing and dentistry; social sciences, including international relations; it is the leading mental health education hospital. (King's College London, 2018)

Tsinghua University is a state-owned research university. Founded in 1911, Tsinghua University is considered one of the best universities in China and ranks 25 th in the world. The university has 14 schools, 56 departments and faculties in humanities, law, medicine, history, philosophy, economics, management, education and arts. The strengths of the university are: comprehensive assistance to talented researchers; cooperation with 149 research institutes, including 13 state laboratories; the Tsinghua campus, located in the north-west of Beijing, is one of the most beautiful in the world. (Tsinghua University, 2018)

This analysis of the top 25 world-class research universities describes their strengths and characterizes the key areas of their in-depth specialization. In the following, their student potential is shown and the total number of students in these research universities is analysed and compared (Fig. 2).

Figure 2. The number of students in research universities of the world

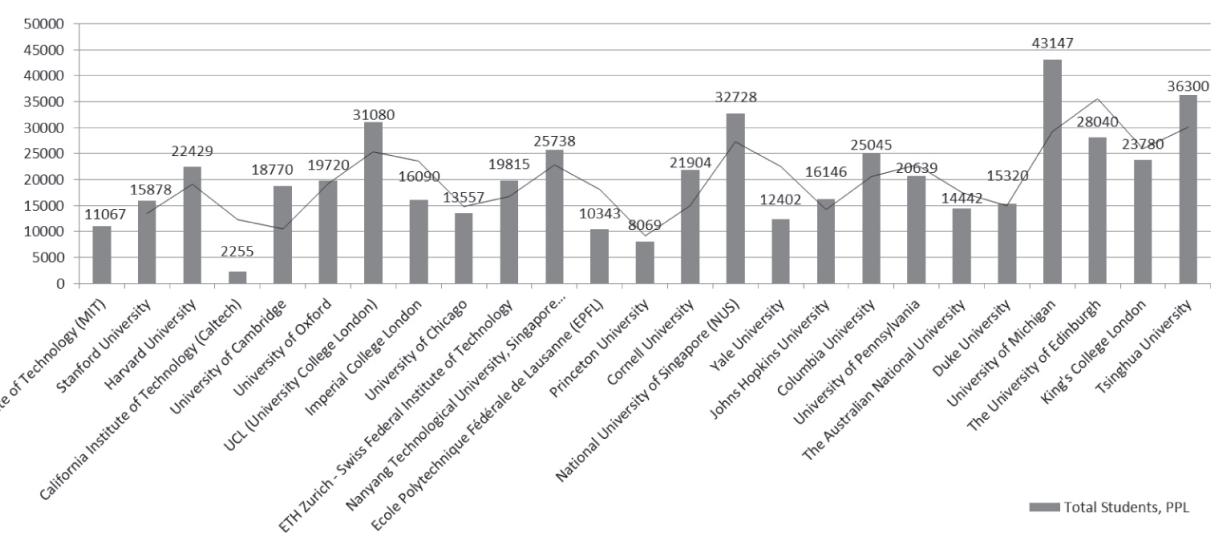

Source: Compiled by the author on the basis of QS World University Rankings, 2018 
The number of students, shown in Figure 2, reveals an interesting trend. The trend indicates that the number of students in top five leading research universities in the world is not larger compared to the universities listed below the top five. The difference in the number of students between the first and last university in the rating is 25,233 in favor of the latter. The number of foreign students is given in Figure 3.

Figure 3. The number of foreign students in the world's research universities

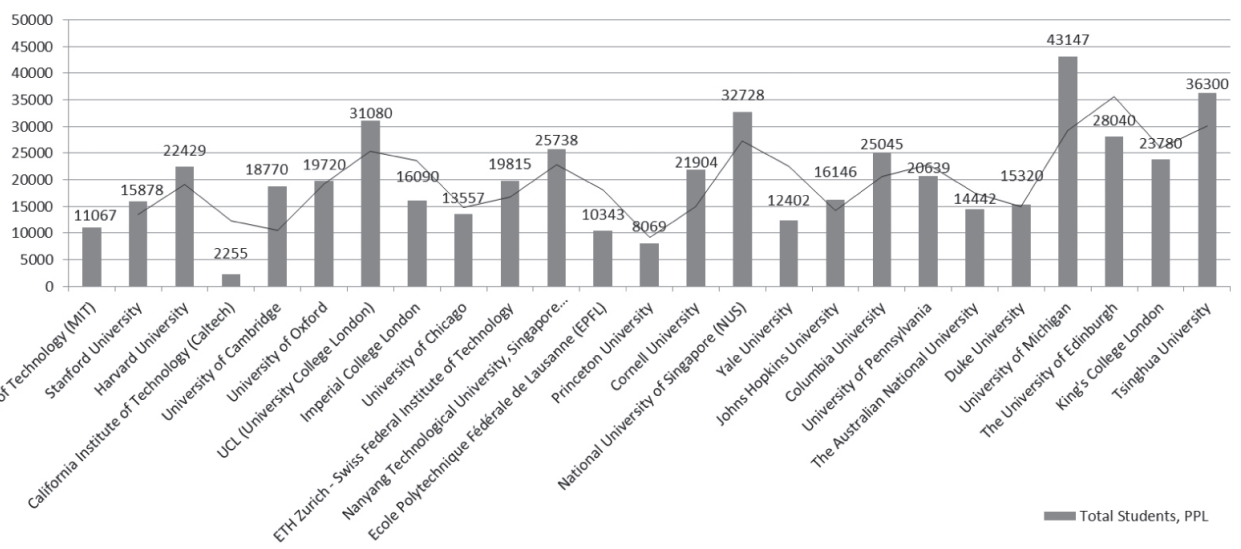

Source: Compiled by the author on the basis of QS World University Rankings, 2018

The number of foreign students, shown in Figure 3, also shows an interesting trend. The indicator is important in terms of influencing the internationalization of academic and research activities in the universities, but, as can be seen from the graph, it is not a determining factor in the rating position.

An example of this trend is the California Institute of Technology (Caltech), which ranks 4th in the ranking, but has only 647 foreign students, which is, in fact, the lowest number among all 25 research universities. University College London (UCL) has the largest number of foreign students-14,854. The difference in the number of foreign students between the universities occupying the first and the last place in the QS rating, is 355 in favor of the university occupying the last place, the 25 th. The graph confirms (Fig. 3) that UK research universities are the unquestionable world leaders in the number of foreign student admissions. Figure 4 shows indicators of the number of staff in research universities in the world, revealing significant variations. The number demonstrates a characteristic feature of US research universities - a smaller number of staff with leading positions in the QS ranking and a large number of students. The top three leaders with the largest number of staff are:

1) University of Michigan - 6,809 people, 22nd in the QS ranking; 
Figure 4. The number of staff in research universities in the world

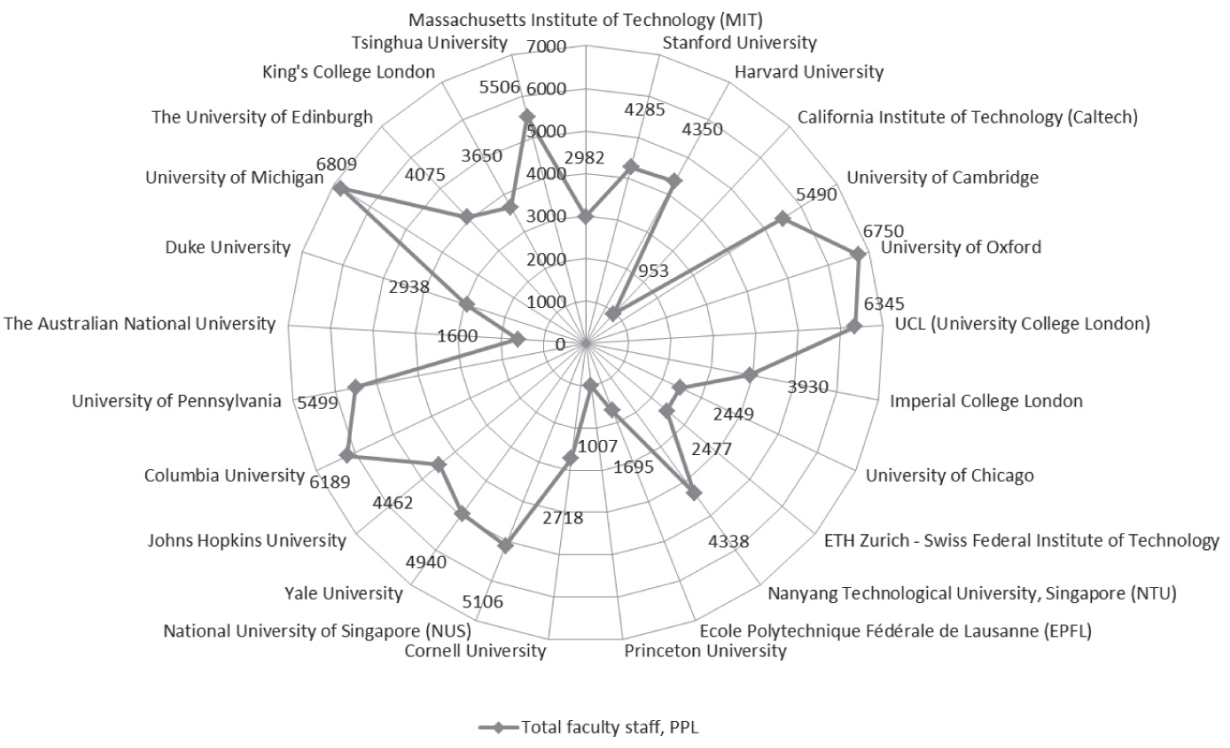

Source: Compiled by the author on the basis of QS World University Rankings, 2018

2) University of Oxford-6,750 people, 6th in the QS ranking;

3) University College London-6,345 people, 7th in the QS ranking.

Caltech has the smallest number of staff-953 people, ranking 4th in the QS. The difference between the first and last place in terms of the number of staff is 5,856 people.

Figure 5 provides the indicators of the ratio of the number of students to the number of staff in the leading research universities in the world.

Figure 5 indicates that the California Institute of Technology in the US has the lowest ratio of students to staff- 2.37 students per staff representative. The Cornell University in the US shows the highest ratio of 8.06. This indicates different approaches, even within the framework of one country, in the organization of educational and research processes and the formation of a university development strategy. British research universities have the lowest scores with the University of Oxford having 2.92 students per staff representative, and the highest with the University of Edinburgh with its 6.88 ratio. Swiss universities have the best ratio of 6.1 at École Polytechnique Fédérale de Lausanne and the worst at ETH Zurich - Swiss Federal Institute of Technology-8.0. Among Singapore's research universities, the Nanyang Technological University has the lowest ratio of 5.93 and the ratio is the highest at the National University of Singapore (NUS) - 6.41. 
Figure 5. Ratio of the number of students to the number of staff in research universities in the world

\begin{tabular}{|c|c|c|}
\hline massachusetts Institute of Technology (MIT) & - Stanford University & w Harvard University \\
\hline - California Institute of Technology (Caltech) & - University of Cambridge & University of Oxford \\
\hline UCL (University College London) & Imperial College London & University of Chicago \\
\hline ETH Zurich - Swiss Federal Institute of Technology & Nanyang Technological University, Singapore (NTU) & ) Ecole Polytechnique Fédérale de Lausanne (EPFL) \\
\hline - Princeton University & - Cornell University & National University of Singapore (NUS) \\
\hline - Yale University & Johns Hopkins University & = Columbia University \\
\hline " University of Pennsylvania & The Australian National University & Duke University \\
\hline Eniversity of Michigan & whe University of Edinburgh & Ming's College London \\
\hline
\end{tabular}

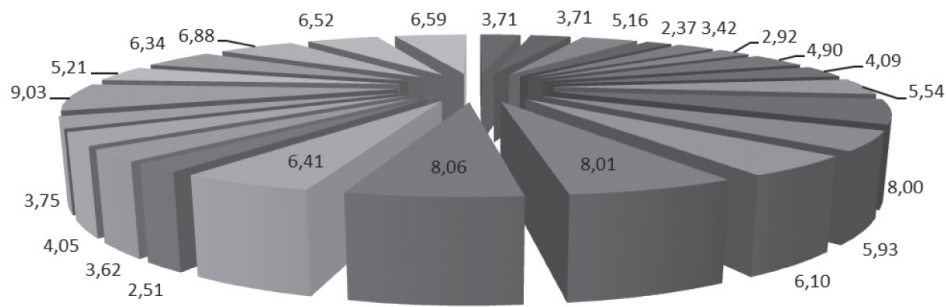

Source: Compiled by the author on the basis of QS World University Rankings, 2018

In the ranking there is also one Australian university - the Australian National University - with a ratio of 9.03 and one Chinese university - the Tsinghua University with a ratio of 6.59 .

Figures 6, 7 and 8 present the assessments of experts according to the main indicators of the world's research universities in the QS rating.

Academic Reputation indicator (Fig. 6) shows the leading positions of eight research universities from the United States, Great Britain and Singapore that have an expert evaluation of $100 \%$. The lowest rating of experts $(83 \%)$ is in the Swiss university École Polytechnique Fédérale de Lausanne. According to the Citations per Faculty indicator, the highest estimate is $100 \%$, received by only two universities in the US, while the University of Edinburgh, Great Britain, shows the lowest score of $55.5 \%$.

Employer Reputation indicator (Fig. 7) shows the maximum expert scores $(100 \%)$ in three US universities and three universities in the UK. Johns Hopkins University, US has the lowest score- $66.4 \%$. The highest rate in the Faculty Student indicator (100\%) is achieved by seven US universities and three universities in the UK. The Australian National University has the lowest indicator $-55.3 \%$. 
Figure 6. The importance of Academic Reputation and Citations per Faculty evaluation indicators in the world's research universities, \%

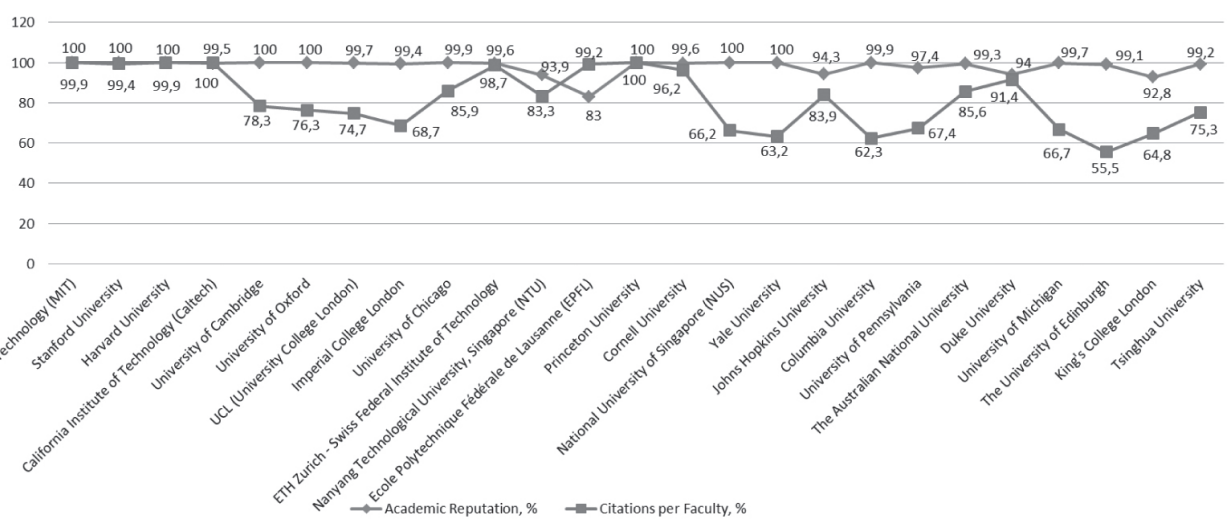

Source: Compiled by the author on the basis of QS World University Rankings, 2018

Figure 7. The importance of Employer Reputation and Faculty Student evaluation indicators in the world's research universities, \%

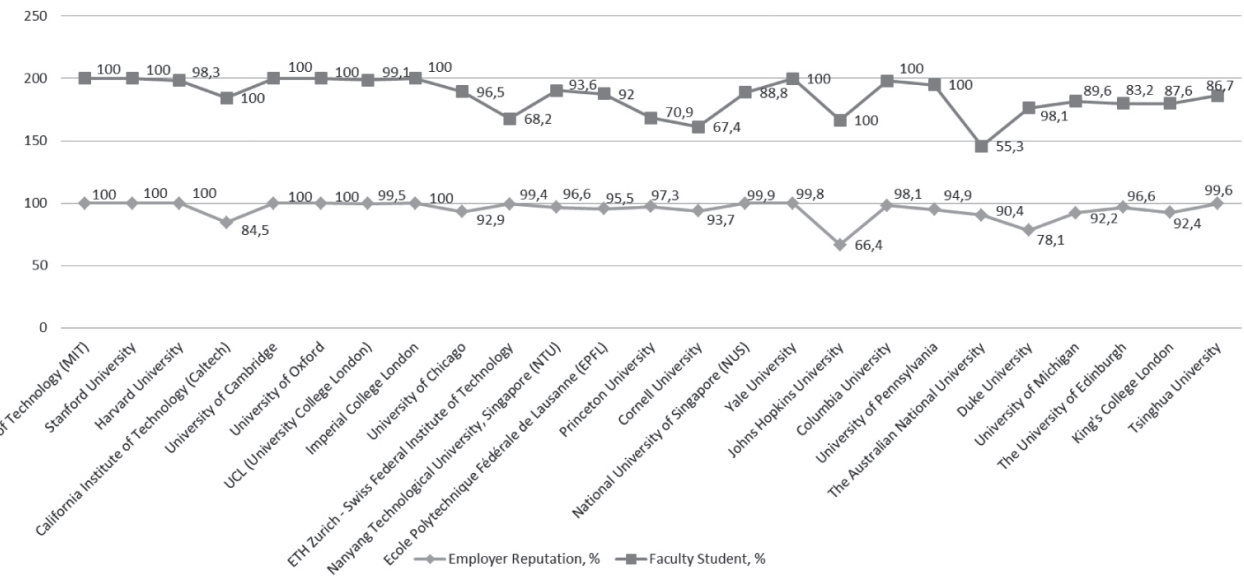

Source: Compiled by the author on the basis of QS World University Rankings, 2018

International Faculty assessment (Fig. 8) indicates the highest scores (100\%) of one university of the United States, Great Britain, Singapore and Australia and two Swiss universities. Columbia University has the lowest indicator of $34.7 \%$ and no information was available for Duke University. According to the International Students indicator, one Swiss and two English universities have the maximum score of $100 \%$, and the Tsinghua University, China has the lowest score of $25.6 \%$. 
Figure 8. The importance of the International Faculty and International Students evaluation indicators in the world's research universities, \%

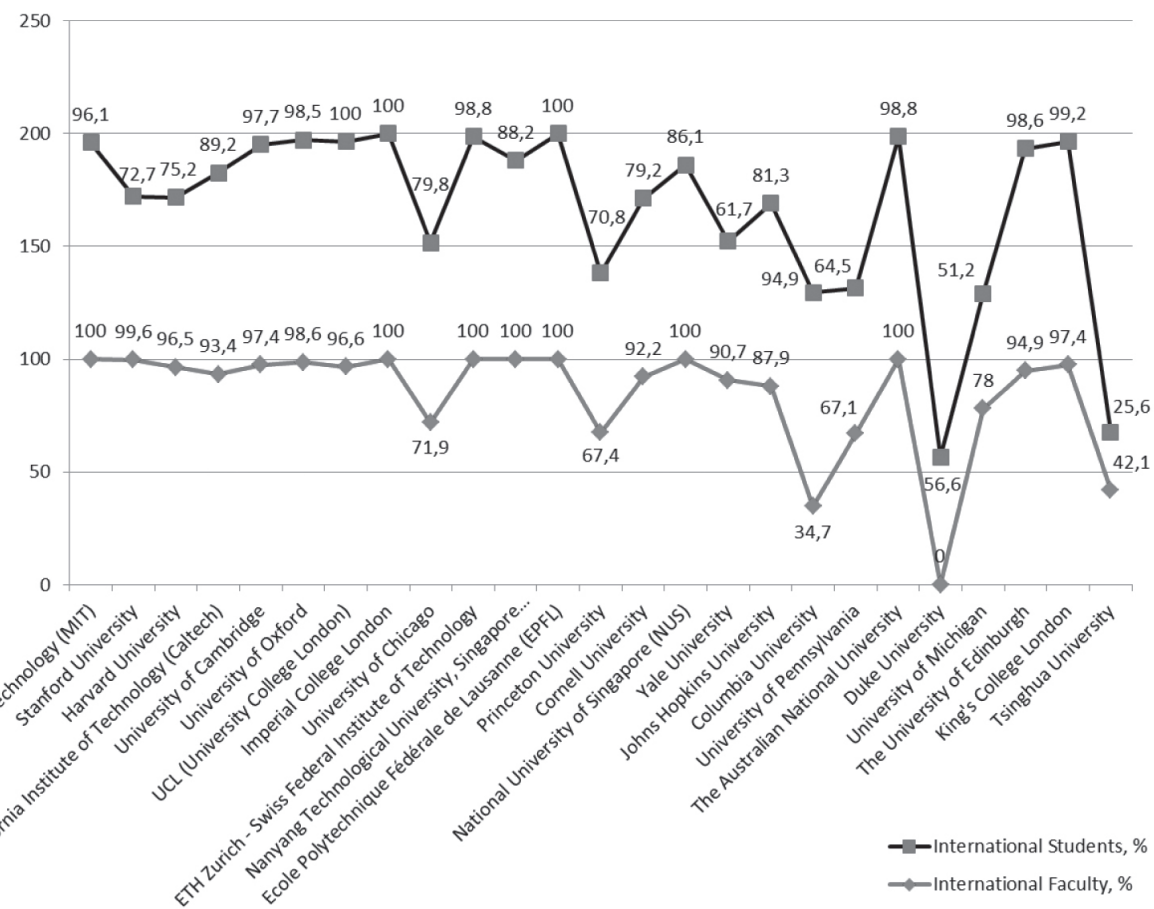

* Duke University does not have data on the International Faculty indicator.

Source: Compiled by the author on the basis of QS World University Rankings, 2018

\section{Conclusions, proposals and recommendations}

On the basis of the main ranking indicators of world-class research universities, the following conclusions could be drawn.

An analysis of modern scientific sources revealed the opinion of the leading scientists of Europe and the world about the development of research universities. The scientists stress the importance of international cooperation of research universities in the fields of academic mobility and scientific research. The global challenges and prospects that research universities of the European Union and the world are facing today were summed up and the experience of implementing joint scientific projects of the EU countries was analysed. A modern trend in the development of research universities was revealed in the direction of 
strengthening their leadership potential and developing entrepreneurial thinking.

The characterization of 25 best research universities in the world enabled the author to determine their strengths and systematize key areas of in-depth specialization. Comparing the total number of students, foreign students and the staff of research universities, there proved to be significant disparities that show radically different approaches to organizing educational and research processes, even within a single country. The ratio of student per staff representative and the comparison of the systematized indicators of the global university QS rating were calculated. The ratio allows showing the contrasting differences between the analysed research universities and clarifying the key development priorities for the European Union research universities.

Having identified the main trends in the development of research universities in the world, it should be noted that even now the research universities of the European Union should revise their development strategy. Mainly UK universities are featured in the top 25, while other EU universities a represented in the global ranking of the QS with only the 43rd position (École normale supérieure, Paris). Given BREXIT, such a situation is unacceptable and threatening for the EU research universities. To strengthen its position in the global QS rating and the level of international competitiveness of EU research universities, it is necessary to achieve high results in the following key areas:

1) Academic reputation, the number of foreign students. In this aspect, the research universities of the European Union need to improve the effectiveness of exchange programs, both among the EU Member States themselves and with the third countries. The relative number of foreign teachers and students should grow. This will build a positive image of universities at the global level and unite networks and groups with scientific interests. This is the development strategy implemented by research universities in the United States, the United Kingdom and Singapore with the maximum score of assessment of experts on this indicator. At the same time, the use of grant opportunities, Nobel Prize laureates and winners of other important competitions, titles of "honorary professor of the university", would enhance the positive image of European universities of research and attract the leading specialists in the world to the educational and research processes. It is necessary to ensure a systematic increase in the ability of research universities to carry out assigned scientific tasks for a limited period of time, and possibly in conditions of limited resources. Also, it is necessary to expand the base and the level of attracted resources to R\&D from alternative sources of financing. This will show the interest of representatives of the 
business environment, the state, other public entities and private investors in the effectiveness and results of the work of research universities and will strengthen the image index of their level of self-sufficiency.

2) Improvement of the ratio of the number of students to the number of staff. The strategic prospect for development of this direction is the optimization of the organizational structure of EU research universities and the number of personnel in them in order to maximize the benefits of individual and team work with students and other categories of job seekers and researchers. In the analysed examples of world-class leading universities, the best indicator is 2.37 students per staff representative. If the British university and the highest-ranking EU university École normale supérieure, with its 43rd place in the ranking (QS World University Rankings, 2018), is excluded from the analysis, then the ratio is 10.71 students per staff representative. Thus, European research universities have not taken advantage of the favorable situation of students having the opportunities to get more attention from staff representatives. This significantly affects the quality of education and is an indicator of students' opinions about the university and the heads or employers who may have been students of these universities themselves and in their time have received less attention in the process of teaching and research.

3) Employers'reputation. Employers should also establish an opinion about the graduates of research universities, even at the stage of preparing students. It is necessary to carry out work by involving employers in the process of training the specialists they need. Thus, European research universities need to develop a set of programs that ensure the involvement of the leading companies in Europe and the world in the educational process and stimulate the results of scientific activities. Such decisions can be the beginning of joint competitions such as 'Graduate-Entrepreneur of the Year', 'Best Scientific Work', 'Best Business Project', and the like. In fact, this is an American model of working with employers in the US universities, implemented by the leading universities in the rating for this indicator. Such cooperation gives its positive results in three main aspects: increasing the motivation of students; involvement of real sector companies in the training of necessary specialists; and financial contribution to the university's budget through charitable donations of employers for the development of research universities.

4) Improvement of the quality and increasing the number of citations of scientific publications of university researchers. The results of the studies show a high citation rate of the Princeton University and the California Institute of Technology (Caltech). Other US universities gained a predominant lead in the expert ratings 
(QS World University Rankings, 2018). In this aspect, it is necessary to ensure the maximum availability of published research papers by researchers of EU universities in international scientific databases. It is also necessary to maximize the combination of the number of external links to university domains and to fill the pages of university websites with current scientific results of global significance. In fact, the news of research universities in Europe about new achievements in the field of science and technology should become the first source of information to the general public. This will generate systematic interest among the scientific community and will increase citation rates. At the same time, it is important to intensify the preparation of publications in co-authorship with colleagues with shared scientific interests from other research universities. Efforts should be enhanced on improving the quality of research results published in university publications with the involvement of authoritative scientists recognized and reviewed by the international community. It is also necessary to revise the systems of certification of the teaching and scientific composition of the staff focusing on a detailed analysis of their merit in the academic sphere rather than the number of published works. A system of awarding employees for significant scientific achievements and publication of their results in academic publications with a high impact factor should be worked out. Profile commissions to assess the value of the scientific works of researchers need to be created and further opportunities for their commercialization considered.

5) Increasing the university's participation in international educational and scientific networks of other countries and continents. The results of the study show a high level of internationalization of universities in the US, the UK, Singapore, Australia and Switzerland. The strategic recommendations for research universities in the European Union in this aspect are a preliminary assessment of their own ability to further expand their participation in international scientific projects and programs. There is a need for the launching of new programs and substantial expansion of financing to the governing bodies of the European Union. This will strengthen the existing scientific potential of research universities and intensify scientific processes, strengthen the presence of European researchers in the sphere of publishing. It is necessary to enhance efforts on the definition of new trends and the formulation of new scientific problems that correspond to the modern development of society and solve the global problems of mankind. The rationality of such a concept is shown on the example of the analysed US research universities which could focus their activities on the global importance of scientific problems rather than on multitasking. When solving these scientific problems, research universities enhance their reputation and gain social and material benefits instead of solving 
a large number of scientific problems of lesser scientific importance. This shows that the research universities in the European Union should focus their research strategies on solving the most prioritized and socially important issues for the humanity and increase their own mark in the digital space of the rapidly globalizing world.

Maksym W. Sitnicki, PhD in Economics, is associate professor at the Department of Management of Innovative and Investment Activity, Faculty of Economics, Taras Shevchenko National University of Kyiv. His research interests are related to the subject of strategic management, development of research universities, intellectual property management, strategic management of enterprises competitiveness, management of development in the information society. ORCID: http://orcid.org/0000-0002-0452-0404

\section{References}

ANU (2018), The Australian National University [Homepage]. Retrieved from http:// www.anu.edu.au/ [accessed 22 Feb 2018]

Caltech (2018), California Institute of Technology [Homepage]. Retrieved from http:// www.caltech.edu/ [accessed 22 Feb 2018]

Cervantes, M. (2017), 'Higher education institutions in the knowledge triangle,' Foresight and STI Governance, vol. 11, no. 2, pp. 27-42. https://doi.org/10.17323/25002597.2017.2.27.42

Chataway, J.; Parks, S. \& Smith, E. (2017), 'How will open science impact on university-industry collaboration?' Foresight and STI Governance, vol. 11, no. 2, pp. 44-53. https://doi.org/10.17323/2500-2597.2017.2.44.53

Columbia University (2018), [Homepage]. Retrieved from https://www.columbia.edu/ [accessed 22 Feb 2018]

Cornell University (2018), [Homepage]. Retrieved from http://www.cornell.edu/ [accessed 22 Feb 2018]

Daugèlienè, R. (2013), 'Theoretical considerations about the possible impact of globalisation on Europe's economic development,' Baltic Journal of European Studies, vol. 3, no. 2(14), pp. 2-16. https://doi.org/ 10.2478/bjes-2013-0010

Duke University (2018), [Homepage]. Retrieved from https://www.duke.edu/ [accessed $22 \mathrm{Feb} 2018]$

École normale supérieure (2018), [Homepage]. Retrieved from http://www.ens.fr/ [accessed 22 Feb 2018]

Eghbal, F.; Hoveida, R.; Seyadat, S. S.; Samavatyan, H. \& Yarmohammadian, M. H. (2017), 'The effect of talent management process on the research performance of 
faculty members with the mediating role of organizational justice,' Foresight and STI Governance, vol. 11, no. 2, pp. 83-91.

https://doi.org/10.17323/2500-2597.2017.2.83.91

EPFL (2018), École Polytechnique Fédérale de Lausanne [Homepage]. Retrieved from https://www.epfl.ch/ [accessed 22 Feb 2018]

ETH Zurich (2018), ETH Zurich - Swiss Federal Institute of Technology [Homepage]. Retrieved from https://www.ethz.ch [accessed 22 Feb 2018]

Gunther, J.; Latifi, G.; Lubacha-Sember, J. \& Tobelmann, D. (2017), 'Scientific cooperation in a German-Polish border region in the light of EU Enlargement,' Foresight and STI Governance, vol. 11, no. 1, pp. 42-53. https://doi.org/10.17323/2500-2597.2017.1.42.53.

Harvard University (2018), [Homepage]. Retrieved from https://www.harvard.edu/ [accessed 22 Feb 2018]

Imperial College London (2018), [Homepage]. Retrieved from http://www.imperial. ac.uk/ [accessed 22 Feb 2018]

Johns Hopkins University (2018), [Homepage]. Retrieved from https://www.jhu.edu/ [accessed 22 Feb 2018]

Junevičius, A. \& Daugèlienè, R. (2016), 'Restrictions on European Union citizens' freedom of movement and residence in the country on grounds of public policy, public security and public health,' Baltic Journal of European Studies, vol. 6, no. 1(20), pp. 48-68. https://doi.org/10.1515/bjes-2016-0003

Keikha, A.; Hoveida, R. \& Yaghoubi, N. M. (2017), 'The development of an intelligent leadership model for state universities,' Foresight and STI Governance, vol. 11, no. 1, pp. 66-74. https://doi.org/10.17323/2500-2597.2017.1.66.74

Kerikmäe, T. \& Chochia, A. (2016), Political and Legal Perspectives of the EU Eastern Partnership Policy, Cham: Springer. https://doi.org/10.1007/978-3-319-27383-9.

King's College London (2018), [Homepage]. Retrieved from https://www.kcl.ac.uk/ [accessed 22 Feb 2018]

Kurbatov, S. (2008), 'Universytetski reitynhy yak indykator stanu osvity' [University rankings as an indicator of the state of education], Filosofiia osvity: naukovyi chasopys, vols. 1-2(7), pp. 309-317.

Kurbatov, S. (2015), 'University rankings and their influence on contemporary academic policy,' Annales Scientia Politica, vol. 4, no. 2, pp. 75-79.

MIT (2018), Massachusetts Institute of Technology [Homepage]. Retrieved from http://web.mit.edu/ [accessed 22 Feb 2018]

Murashova, E. \& Loginova, V. (2017), 'University-industry interaction trends in the Baltic Sea Region: a bibliometric analysis,' Baltic Journal of European Studies, vol. 7, no. 2(23), pp. 28-58. https://doi.org/ 10.1515/bjes-2017-0009

NTU (2018), Nanyang Technological University, Singapore [Homepage]. Retrieved from http://www.ntu.edu.sg/ [accessed 22 Feb 2018] 
NUS (2018), National University of Singapore [Homepage]. Retrieved from http://www.nus.edu.sg/ [accessed 22 Feb 2018]

OECD (2017), Science, Technology and Industry Scoreboard. http://dx.doi.org/10.1787/20725345

Pavlenko, A.; Antoniuk, L. \&Vasylkova, V. (2014), Doslidnytski universytety: svitovyi dosvid ta perspektyvy rozvytku v Ukraini [Research Universities: Global Experience and Development Prospects in Ukraine], Kyiv: KNEU.

Perez Vico, E.; Schwaag Serger, S.; Wise, E. \& Benner, M. (2017), 'Knowledge triangle configurations at three Swedish universities,' Foresight and STI Governance, vol. 11, no. 2, pp. 68-82. https://doi.org/10.17323/2500-2597.2017.2.68.82

Princeton University (2018), [Homepage]. Retrieved from https://www.princeton.edu/ [accessed 22 Feb 2018]

QS World University Rankings (2018), [Homepage]. Retrieved from https://www. topuniversities.com/university-rankings/world-university-rankings/2018 [accessed 22 Feb 2018]

Säär, A. \& Rull, A. (2015), 'Technology transfer in the EU: exporting strategically important ICT solutions to other EU Member States,' Baltic Journal of European Studies, vol. 5, no. 2(19), pp. 5-29. https://doi.org/10.1515/bjes-2015-0011

Schuch, K. (2014), 'Participation of the "new" EU Member States in the European research programmes - a long way to go,' Foresight and STI Governance, vol. 8, no. 3, pp. 6-17. https://doi.org/10.17323/1995-459x.2014.3.6.17

Sitnicki, M. (2018), 'Exploration of the role of business schools in the development of world-class research universities,' Technology Audit and Production Reserves, vol. 1, no. 5(39), pp. 36-45. https://doi.org/10.15587/2312-8372.2018.124674

Stanford University (2018), [Homepage]. Retrieved from https://www.stanford.edu/ [accessed 22 Feb 2018]

Supyan, V. (2009), Issledovatelskiye universitety SShA: mekhanizm integratsii nauki $i$ obrazovaniya [US Research Universities: A Mechanism for Integrating Science and Education], Moscow: Magistr.

The University of Edinburgh (2018), [Homepage]. Retrieved from https://www.ed.ac. uk/ [accessed 22 Feb 2018]

Tsinghua University (2018), [Homepage]. Retrieved from http://www.tsinghua.edu.cn/ [accessed 22 Feb 2018]

UCL (2018), University College London [Homepage]. Retrieved from https://www.ucl. ac.uk/ [accessed 22 Feb 2018].

Unger, M. \& Polt, W. (2017), 'The knowledge triangle between research, education and innovation - a conceptual discussion,' Foresight and STI Governance, vol. 11, no. 2, pp. 10-26. https://doi.org/10.17323/2500-2597.2017.2.10.26

University of Cambridge (2018), [Homepage]. Retrieved from http://www.cam.ac.uk/ [accessed 22 Feb 2018] 
University of Chicago (2018), [Homepage]. Retrieved from https://www.uchicago.edu/ [accessed 22 Feb 2018]

University of Michigan (2018), [Homepage]. Retrieved from https://www.umich.edu/ [accessed 22 Feb 2018]

University of Oxford (2018), [Homepage]. Retrieved from http://www.ox.ac.uk/ [accessed 22 Feb 2018]

University of Pennsylvania (2018), [Homepage]. Retrieved from https://www.upenn. edu/ [accessed 22 Feb 2018]

Yale University (2018), [Homepage]. Retrieved from https://www.yale.edu/ [accessed 22 Feb 2018]

Zhylinska, O. \& Sitnitskiy, M. (2018), 'Strategic analysis and evaluation of a research university's performance,' in S. Mărginean, C. Ogrean \& R. Orăștean (eds.) Emerging Issues in the Global Economy: Springer Proceedings in Business and Economics, Cham: Springer, pp. 407-417. https://doi.org/10.1007/978-3-31971876-7 36 